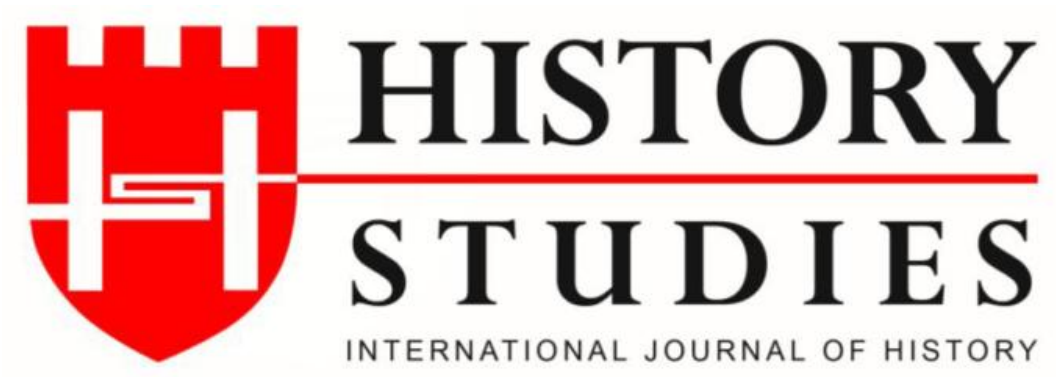

ISSN: 13094173 (Online) 1309 - 4688 (Print)

Volume 12 Issue 5, October 2020

DOI Number: 10.9737/hist.2020.921

Araştırma Makalesi

Makalenin Geliş Tarihi: 13.08.2020 Kabul Tarihi: 14.09.2020

Atıf Künyesi: Ercüment Yıldırım, “Hititlerdeki Tahta Geçiş Sisteminin Çağdaşı Olan Mısır Krallığı ile Kiyaslanması", History Studies, 12/5, Ekim 2020, s. 2299-2317.

\title{
Hititlerdeki Tahta Geçiş Sisteminin Çağdaşı Olan Mısır Krallı̆̆ı ile Kıyaslanması
}

Comparison of Ascend the Throne System in Hittites with the It's Contemporary King of Egypt

\author{
Doç. Dr. Ercüment Yıldırım \\ ORCID No: 0000-0001-5376-4061 \\ Sütçü İmam Üniversitesi- Kahramanmaraş
}

\section{$\ddot{\mathbf{O} z}$}

Monarşik sistemlerin en büyük sorunu iktidarın devri meselesi olmuştur. Tarih boyunca birçok krallığın zayıflamasına veya yıkılmasına yol açan süreçlerin başlangıcında taht mücadeleleri yer almaktadır. Bu genel tespitin dışında Hitit ve Mısır Krallıkları da kalmamış çağdaş olduğu dönemde iki krallıkta da birçok taht mücadelesi yaşanmıştır. Her iki krallığın güçlü kralları, tahta geçiş sistemini düzenlemek için tedbirler almış olsa dahi kalıcı bir başarı elde edilememiştir. Hitit ve Mısır Krallıkları'nda, kral, soya bağlı olarak belirlenmesine rağmen hem aynı soydan olanlar hem de kraliyet ailesine evlilik ile katılanlar tahta geçebilmek için kanlı mücadeleler vermiştir. Hititlerde genel olarak uygulanan büyük oğulun yoksa büyük kızın eşinin tahta çıkması geleneği Mısır'da çok kabul görmemiştir. Özellikle kraliyet ailesine evlilik ile katılanların oluşturduğu sorunları engellemek için Mısır'da oldukça sıra dışı bir adım atılarak kraliyet ailesi içerisinde evlilikler yapılmıştır. Bu evliliklerden çocuk olmaması veya olan çocukların erken yaşta ölümü ile sakat doğması bu tahta geçiş sisteminden beklenen sonucu vermemiştir. Her iki krallıkta da uygulanan veliaht belirleme sistemi de diğer kral adaylarının isyanlarına ve hatta ülkenin parçalanmasına neden olmuştur. Bu çalışma, Hitit ve Mısır krallıklarındaki geleneksel tahta geçiş sistemleri üzerinde yapılan düzenlemeler ile her iki krallıktaki taht mücadelelerinin genel yapısını ortaya koyarak birbirlerine olan üstünlüklerini ve zayıflıklarını belirlemeyi amaçlamaktadır.

Anahtar Kelimeler: Hitit Krallığı, XVIII. Sülale, II. Seti, Kral Telepinu, Kadeş Antlaşması.

\begin{abstract}
The biggest problem of monarchic systems has been the transfer of potency. Throughout the history, throne struggles take place at the beginning of the processes that led to the weakening or destruction of many kingdoms. Apart from this general determination, the Hittite and Egyptian Kingdoms did not remain. In the period when it was contemporary, many throne struggles were experienced in both kingdoms. Even if the powerful kings of both kingdoms took measures to regulate the throne transition system, there was no permanent success. In the Hittite and Egyptian Kingdoms, although the king was determined to be a lineage, both those of the same lineage and those who joined the royal family with marriage fought bloody
\end{abstract}


struggles. The tradition of the great son, who was generally applied in the Hittites, or the wife of the great girl, to come to the throne was not widely accepted in Egypt. The absence of children from these marriages or the birth of children who were disabled and death at an early age did not give the expected result from this ascend throne system. The ascend throne system applied in both kingdoms also caused the rebellions of other king candidates and even the fragmentation of the country. This study aimed to reveal the general structure of the throne struggles in both kingdoms with the arrangements made on traditional ascend throne system in the Hittite and Egyptian kingdoms. It also aimed to identify the advantages and weaknesses of these two ascend throne system.

Keywords: Hittite Kingdom, Eighteenth Dynasty of Egypt, Set II., King Telepinu, Kadesh Treaty.

\section{Giriş}

İlk şehirlerin oluşmaya başladığı dönemden günümüze kadar insanlığın tabi olduğu yönetim sistemleri içerisinde en yaygın olanı monarşi ya da bir diğer değişle krallık sistemi olmuştur. Bütün monarşik sistemlerde, yönetim, kralın varlığı ile devamlılığını sağlamıştır. Bu sebepten kral, her konuda belirleyici bir role sahip iken başarılı krallar döneminde ülkeler gelişmiş, başarısız krallar döneminde yıkılışa sürüklenmiştir. Monarşik sistemlerin en zayıf yönü ise kralın ölümü ile yeni kralın belirlenmesi arasındaki boşlukta oluşabilecek karmaşa durumudur. $\mathrm{Bu}$ durumu önlemek için tarih boyunca birçok sistem geliştirilmesine rağmen hiçbiri kalıcı bir başarı gösterememiştir. $\mathrm{Bu}$ başarısızlığın temelinde, tahta geçmek isteyen birçok oğulun varlığı, hanedan ailesine akrabalık yolu ile sonradan katılanların iktidar mücadelesine girmesi, kralın yönetimi döneminde başarılar kazanmış yüksek düzeyli görevlilerin sahip olduğu prestiji kullanarak kral olma isteği gibi sebepler bulunmaktadır.

Yöneteceği insanların ve ülkenin kaderini belirleyecek kadar önemli bir olay olan yeni kralın seçimi, eskiçağ toplumlarında genelde hanedan ailesi içerisinde gerçekleșmiștir. Kralın seçimindeki en belirleyici unsur, bir önceki kral tarafindan adaylardan birinin veliaht olarak gösterilmesidir. Veliaht gösterme ya da belirleme görece basit ama etkili bir sistemdir. Fakat savaş, hastalık ve suikast gibi sebeplerle kralların ani ölümü geride bir veliaht bırakamamasına yol açabilmekteydi. Bunun yanı sıra veliaht olarak belirlenen kişiyi, tahtın diğer adaylarının kabullenmemesi de iç savaşlara neden olabilmekteydi. Zamanla bu sorunu çözebilmek için daha basit bir yöntem yaygınlaşmış ve kralın en büyük oğlunun kral olması genel bir teamül haline gelmiştir. Bu çözümün en zayıf yönü ise kralın bir erkek evladının bulunmayışı olmuştur. Bu durumda ise ölen kralın en büyük kızının eşi kral kabul edilmiştir. Fakat kraliyet soyuna mensup olmayan damadın kral oluşu pek çok durumda siyasi olarak da güçlü olan komutanların, isyanına sebep olmuştur. Ayrıca kraliyet ailesine sonradan katılan ve kök soya mensup olmayan damatlar arasından güçlü krallarında çıkmadığı görülmüştür. İhtimal dahilindeki bütün bu durumlar, tarih boyunca krallık seçimini oldukça çetrefilli bir hale getirmiştir.

Bu çalışmada MÖ II. binyılın en güçlü iki merkezi yönetimi olan Hitit ve Mısır krallıklarında uygulanmış olan tahta geçiş sistemleri incelenip eldeki kayıtlar üzerinden bir kıyaslama yapması amaçlanmaktadır. Çalışmada görüleceği üzere birbiri ile çağdaş olan ve aralarında diplomatik ilişkiler ile savaşların yaşandığı bilinen Hitit ve Mısır krallıkları, yeni kralın belirlenmesinde benzer ve birbirinden farklı yöntemler kullanmışlardır. Her iki toplumun kullanmış olduğu bu yöntemlerin güçlü ve zayıf yönleri, çalışmanın temel problematiğini oluşturmaktadır. Ayrıca çalışmada, her iki krallığın toplumsal yapısının ve yönetim anlayışının farklılığının tahta geçiş sistemine olan etkisi üzerinde durulacaktır. 


\section{Hitit Tahta Geçiş Sistemi}

Anadolu, insanlık tarihinin ilk dönemlerinden itibaren sahip olduğu doğal kaynakların zenginliğinden dolayı yoğun bir nüfusu barındırmıştır. Bu duruma rağmen komşu coğrafyaları olan Mısır ve Mezopotamya'ya göre yazıyı daha geç kullanmaya başlamıştır. Yazının geç kullanımının en önemli sebebi ise Anadolu'da erken dönemlerde merkezi bir yönetimin oluşmayışıdır. Birbirinden bağımsız şehir devletlerinden meydana gelen bir yapının binlerce yı1 boyunca Anadolu'yu yönettiği sonrasında ise yeni bir toplumun göç yolu ile geldiği bilinmektedir. Aryan göçlerinin bir parçasını oluşturduğu varsayılan Hititlerin Anadolu'ya gelişinin MÖ. 1800 - 1700'lü yıllarda gerçekleştiği düşünülmektedir. Sızma şekilde gerçekleşen bu göç hareketinden sonra Hititler, nüfus yoğunluğunu sağladıkları Anadolu'nun bazı kentlerinde siyasi örgütlenmeler oluşturmuşlardır. Boğazköy'de bulunan bir metinde, Hitit kökenli olduğu kabul edilen Kussarra Kralı Anitta'nın, Neşa, Zalpa, Hattuşa gibi diğer kent devletlerini ele geçirdiği ve merkezi bir yönetim kurmaya çalıştığı görülmektedir. ${ }^{1}$

Kussarra Kralı Anitta ile başlayan Hitit siyasi tarihinde tam anlamıyla merkezi bir krallık kurmayı başaranın I. Hattuşili olduğu kabul edilmektedir. I. Hattuşili, krallığının başlangıcında Orta Anadolu'nun güneydoğusuna lokalize edilen Kussara kentinde hüküm sürerken jeopolitik nedenlerden dolayı kraliyet kentini bir Hatti şehri olan Hattuş'a taşımış ve ismini bu kentten almıştır. I. Hattuşili'nin bir diğer büyük başarısı ise Babil çivi yazısının Hitit diline uyarlanmasıdır. Çivi yazısını kullanmaya başlayan Hitit yönetici sınıfı, bu yazı ile hukuki ve idari düzenlemeler gerçekleştirmişlerdir. Hitit krallığının kurucusu kabul edilen I. Hattuşili, bu büyük başarılarına rağmen kendisinden sonraki kralı belirlemede sorunlar yaşamıştır. ${ }^{2}$

\footnotetext{
"Büyük Kral Tabarna soylular topluluğuna ve ileri gelenlere seslendi: "Bakın, ben hasta oldum ve size genç Labarna'nın (veliahdımın) adını vermiştim; o tahta geçecekti ve ben Kral, onu oğlum yaptım, kucakladım ve yükselttim. Her zaman onunla ilgilendim. Ancak, o, bu çocuk nasıl davrand, bu olacak şey değildi. O hiçbir gözyaşı dökmedi, hiçbir merhamet göstermedi; soğuk ve kalpsiz. (...) O, Kralın sözünü dinlemedi, anasının sözünü, o yılanın sözünü dinledi. Ve erkek kardeşleriyle kız kardeşleri ona, arabozucu sözler taşıdılar; onların sözlerine kulak verdi. Ve bunu, ben kral duydum. Böylece savaşa savaş açıyorum. Yeter artık. O, bundan böyle benim oğlum değil." 3
}

I. Hattuşili'nin veliaht olarak belirlenen yeğenin yerine torunu olan Murşili'yi getirmesi anlatan metnin giriş kısmında Kral, veliaht seçmede yaşamış olduğu talihsizliği anlatmaktadır. Öncelikle metinden, Hititlerin veliaht belirleme sistemini kullanmış oldukları anlaşılmaktadır. Fakat göze çarpan ilk ayrıntı, I. Hattuşili'nin kendisinden sonra kral olacak kişiyi oğlu yaptığını belirtmesidir. Bu durum ilk belirlenen veliahdın kralın oğlu olmadığını ancak hanedan ailesine mensup biri olduğunu göstermektedir. Metnin devamına bakıldığında bu kişinin I. Hattuşili'nin yeğenlerinden biri olduğu çıkarımı yapılabilir. Fakat kral olması için belirlenen bu yeğenin, Kral henüz hayatta iken uygunsuz davranışlar sergilediği ve kardeşlerinin tesirinde kaldığ anlaşılmaktadır. Bunun üzerinde I. Hattuşili, belirlediği ilk veliahttan vazgeçmiş ve onun artık oğlu olmadığını ilan etmiştir. ${ }^{4}$

\footnotetext{
${ }^{1}$ Giulia Torri, "Sargon, Anitta, and the Hittite Kings against Purušhanda", Altorientalische Forschungen, C. 36 S. 1, 2009, s. 110 - 118.; Alfonso Archi, "How the Anitta Text Reached Hattusa", Saeculum. Gedenkschrift für Heinrich Otten Anlässlich Seines, S. 100, 2015, s. 1 - 13.; Amir Gilan, "Hittite Ethnicity? Constructions of Identity in Hittite Literature", Anatolian Interfaces: Hittites, Greeks and Their Neighbours, Ed. Jean Collins, Mary R. Bachvarova, Ian Rutherford, Oxbow Books, Oxford 2008, s. 107 - 115.; J. G. Macqueen, Hititler ve Hitit Çağında Anadolu, Arkadaş Yayınları, Ankara 2013, s. 21 - 22.; Özlem Sir Gavaz, "Hitit Kenti Zalpa'nın Yeri Üzerine", Anadolu, S.31. s. 1 - 18. ${ }^{2}$ B. J. Collins, "Hattušili I, the Lion King”, Journal of Cuneiform Studies, C. 50, S. 1, 1998, s. 15 - 20.; Trevor Robert Bryce, "The Annals and Lost Golden Statue of the Hittite King Hattusili I", Gephyra, 16, 2018, s. 1 - 12.

${ }^{3}$ Ekrem Akurgal, Hatti ve Hitit Uygarlıklarl, Tükelmat, İzmir 1995, s. 282.

${ }^{4}$ Turgut Yiğit, "Hitit Kral Ailesi Üyelerinin Siyasal Etkinlikleri Üzerine”, Tarih Araştırmaları Dergisi, C. 18, S. 29, 1996, s. 233 - 245.; Veli Ünsal, Eski Anadolu’da Teokratik Devlet Düzeni Hitit ve Urartu, Berikan Yayınevi, Ankara
} 
“Ben, Kral, ona (ilk veliahdıma) bir kötülük mü işledim? Onu rahip yapmadım mı? Her zaman onun iyiliğini düşündüm ve onu takdir ettim ama o benim, kralın isteğine sevgi ile karşıllı vermedi. (...) Onun anası (ihtimalle I. Hattuşili'nin erkek kardeşinin eşi) bir yılandır! Ve şöyle olacaktır: Anasının, erkek kardeşlerinin (ve) kız kardeşlerinin sözlerini dinleyecektir. Bakın, (siz soylular topluluğu ve ileri gelenler) kral uğruna, teker teker öleceksiniz ve öyle olacaktır; o hepinizi mahvedecektir. (...) Ben dışarıdaki düşmanlarımı kılıçla yendim ve ülkemi huzur ve barış içinde tutum. Şimdi (bu iş) oraya varmamak ve o ülkemi kargaşaya sürüklememelidir. Artık bundan sonra o şehirden aşă̆ inip istediği yere salınarak gitmemelidir. Bakın ben ona bir ev verdim; ona yeterince toprak verdim. (...) Uslu oturduğu sürece yesin içsin; istediğinde eskisi gibi, yukarlya kente gelsin. Ancak can sıkacak davranışta bulunursa, ya da herhangi bir kötülük, herhangi bir bozgunculuk yaparsa yukarlya kente gelmesin, evinde otursun",5

I. Hattuşili, metnin devamında tahttan men ettiği ilk veliahda karşı herhangi bir ayrımcılık yapmadığını ve onu ihmal etmediğini açıklamaktadır. Sonrasında ilk veliahdın tahta geçip kral olması durumunda ülkeyi bekleyen tehlikeyi anlatan I. Hattuşili, ona yine bir kötülük yapmadığını sadece yönetim merkezinin bulunduğu yukarı şehirden aşağı şehre sürgün ettiğini belirtmektedir. Hitit krallarının, yönettikleri üzerinde sınırsız yetkisi bulunmasına rağmen kraliyet ailesinin mensuplarının öldürtmesinin hoş karşılanmadığ 1 bilinmektedir. Bu sebepten dolayı sürgün cezasının seçilmiş olması muhtemeldir. Metinde dikkat çeken bir diğer durumda I. Hattuşili'nin, düşmanlarını kılıç ile yendiğini ve ülkesini huzur ve barış içerisinde tutuğunu belirtmesidir. Bu ifade, I. Hattuşili'nin, hakim olduğu coğrafyada kendisine rakip olabilecek bir düşman bırakmadığını göstermekte fakat kralın, bir taht kavgası ile ülkesinin kargaşaya sürüklenmesinden de endişe ettiğini belirtmektedir. ${ }^{6}$

\begin{abstract}
"Bakın buraya, Murşili şimdi benim oğlum. Onu (kral olarak) tanıyacaksınız. Onu tahta oturtacaksınız. Tanrı onun kalbini birçok iyi hasletlerle doldurdu. Bir aslanın yerini, tanrı ancak bir aslana verir. (...) Siz görevlilerim ve ülkenin büyükleri oğlumun yanında olup ona yardımcı olunuz. (...) Artık kavga olmamalı; onun görevlileri bir ananın çocuklarıdır. (...) Babanın sözlerini tut, babanın sözlerini tuttuğun sürece ekmek yiyip su içeceksin. Sizler benim en yüksek görevlilerimsiniz! Ve sizler de kralın sözlerini tutunuz. Sana sözlerimi ilettim ve bu levhayı (tableti) sana aydan aya okusunlar; böylece benim sözlerimi ve tecrübelerimi hep kalbinde saklayacaksın. (...) Cesedimi yıka, gerektiği gibi! Beni göğsüne bastır ve göğünde tutarak beni topră̆a göm. "7
\end{abstract}

I. Hattuşili'nin metninin son kısmı kendisinden sonra tahta çıkmasına karar verdiği I. Murşili'nin ilanına ve ülkenin ileri gelenlerine yapılan ikazlara ayrılmıştır. I. Murşili'nin kendisinden sonra kral olmasına karar verdiğini ülkenin ileri gelenleri önünde açıklayan I. Hattuşili, sözlerinin unutulmaması için de bu tableti yazdırmış olmalıdır. Hatta metinde, tabletin her ay I. Murşili’ye okunmasını da vasiyet eden I. Hattuşili, öğütlerinin tutulması durumunda ekmek yiyip su içeceksiniz yani yaşamlarınızı devam ettireceksiniz demektedir. I. Murşili, dedesi gibi güçlü ve dirayetli bir krallık sürmüştür. Hititlerin geleneksel hale gelecek olan Kuzey Suriye'ye yayılma politikasını sürdürmüş ve Halpa (Halep) krallığına son vermiştir. Devamında Hurri toplumu üzerine başarılı saldırılar gerçekleştirmiş ve nihayetinde Babil’’i ele geçirerek

2013, s. 48 - 51.; Turgut Yiğit, "Eski Hitit Dönemine Ait Bir Ferman", Tarih Araştırmaları Dergisi, S. 41, 2007 , s. 1 -8 .

${ }^{5}$ Akurgal, age, s. 28.

${ }^{6}$ Turgut Yiğit, "Hitit Krallı̆̆ı'nda Veliahdın Belirlenmesi Üzerine”, Tarih Araştırmaları Dergisi, C. 22, S. 34, 2003, s. 141 - 147.; Trevor Robert Bryce, "Hattušili I and the Problems of the Royal Succession in the Hittite Kingdom", Anatolian Studies, S. 31, 1981, s. 9 - 17.; Arif Kumaş, "Hitit Hukuki Metinlerinde Ataerkillik ve Anaerkillik Işı̆̆ında Veraset”, Hitit Üniversitesi Sosyal Bilimler Enstitüsü Dergisi, ANARSAN Sempozyumu Özel Sayısı, 2018, C. 11, S. 2 , s. $1497-1510$.

${ }^{7}$ Akurgal, age, s. 28 - 31. 
Hammurabi sülalesini yıkmıştır. Bütün bu başarılara rağmen I. Murşili, bir saray entrikasına kurban gitmiştir. ${ }^{8}$

\begin{abstract}
“Murşili, Halep'e gitti. Halep'i imha etti. Halep’ten alp getirdiği kişileri ve ganimetini Hattuşa'ya getirdi. Sonra o, Babil'e gitti ve Babil'i imha etti. Hurrili askerleri yendi. Babil'den alıp getirdiği insanlarl ve ganimetini Hattuşa'ya sundu. (O zaman) Hantili saki idi. Murşili'nin kız kardeşi Harapşseli 'yi karısı olarak tutuyordu. Zidanta, Hantili ile birleşti. Kötü bir iş yaptılar ve Murşili yi öldürdüler. Kan döktüler (cinayet işlediler)." 9
\end{abstract}

Kral Telepinu'ya ait olan metinden alınan bu pasajdan, I. Murşili'nin Babil seferinin dönüşünde eniştesi Hantili ve onun kayınbiraderi veya damadı olan Zidanta'nın işbirliği ile öldürülmüş olduğunu öğrenmekteyiz. Bu durum, Hitit kraliyet ailesine evlilik yolu ile sonradan katılmış olan Hantili ve Zidanta'nın da tahtta çıkabilme ihtimalinin bulunduğunu göstermektedir. Eskiçağdaki birçok toplumda soyun babadan geldiğine inanıldığı için kız çocuklarının eşlerinin ve onların çocuklarının tahtta hakları bulunmamaktadır. Fakat Hititlerde, doğum veya evlilik yolu ile kraliyet ailesine mensup olan herkesin kral adayı olduğunu görmekteyiz. Bu anlayış, saray kadınlarının da karıştığı birçok entrikanın ortaya çıkmasına neden olduğu gibi sonu gelmez suikastlara da yol açmaktayd.
"Hantili korktu (ve şöyle dedi): "Korunacak miyım?” O nereye gitti ise, o ülkenin halkı onu sahiplenmedi Aştata, Şukziya, Hurpana, Kargamış (Hantili'ye) asker vermemeye başladılar. (...) Hantili, Tegarama'ya varınca şöyle demeye başladı: "Bunu neden yaptım? Neden damadım Zidanta'nın sözlerini dinledim?” (...) Tanrllar, Murşili'nin kanının intikamın aldllar. (...) Hantili de yaşlanınca, tanrı olmaya başladı (ölüm yatağına düştü). Zidanta, Hantili'nin oğlu (Pişeni'yi) oğulları ile birlikte öldürdü. Önde gelen hizmetkarlarını da öldürdü. Zidanta da kral oldu. Tanrılar Pişeni'nin kanının intikamını aldılar. Ona oğlu Ammuna'yı tanrılar düşman ettiler. Babası Zidanta 'yı öldürdü. Ammuna da kral oldu”" 10

Volume 12

Hantili ve Zidanta tarafından başlatılan bu suikastlar zinciri devam etmiş ve onlar da canlarını haleflerinin elinden kurtaramamıştır. Bu karmaşa dönemi, etnik olarak birçok farklı ulusu yöneten Hititler için oldukça zorlayıcı olduğu aşikardır. Metinde de görüldüğü üzere Hititlere bağlı olan şehirlerin bir kısmı meşruiyetini kabul etmedikleri Hantili’ye asker vermemişlerdir. Krallıkta karışıklık arttığı gibi sarayda da entrikalar durmamış ve hanedana mensup olan aileler arasında mücadeleler devam etmiştir. Babasını öldürerek tahta geçen Ammuna'dan sonra Huzziya tahta geçmiştir. Fakat kraliyet ailesi içerisinde başlayan güvensizlik ortamı yatışmamış, iktidarı elinde tutan kral, başkaldırı ihtimali gördüğü akrabalarının ölüm emirlerini vermekten geri durmamıştır. Hitit krallarını bu ölüm emirlerini vermeye iten temel etkenin kendi yaşamını devam ettirebilme ve tahtını koruma mücadelesi olduğu anlaşılmaktadır. Bu durum iki yönlü bir sonuç ortaya çıkarmış ne zaman öldürüleceğinden emin olmayan hanedan mensupları da ilk firsatta kralı devirip hasımlarını yok etmeye çalışmıştır. Bu durumun en ilginç örneği ise Telepinu'dur. ${ }^{11}$

"Huzziya kral oldu. Telepinu da onun ilk (büyük) kız kardeşi lştapariya ile evli idi. Huzziya onları (az kaldı) öldürecekti. Konu meydana çıktı. Telepinu onları sürdü. (Huzziya'nın) beş

\footnotetext{
${ }^{8}$ Horst Klengel, "Hitit Tarihi”, Hititler ve Hitit İmparatorluğu, Ed. Wenzel Jacob, Kunst-und Ausstellungshalle der Bundesrepublik Deu, Bonn 2002, 414 - 415.; Seton Lloyd, Türkiye’nin Tarihi - Bir Gezginin Gözüyle Anadolu Uygarlıkları, Tübitak, Ankara 1989, s. 33 - 34.; Eva Cancik - Kirschbaum, Asurlular (Tarih, Toplum, Kültür), Çev: Aslı Yarbaş, İlya Yayınları, İzmir 2004, s. 51.

${ }_{9}^{9}$ Akurgal, age, s. 32.; Sedat Alp, Hitit Çă̆ında Anadolu, Tübitak, İstanbul 2000, s. 59

${ }^{10}$ Alp, age. s. $59-60$.

${ }^{11}$ Füruzan Kınal, Eski Anadolu Tarihi, Türk Tarih Kurumu, Ankara 1998, s. 89 - 90.; Richard H. Beal, "Studies in Hittite History", Journal of Cuneiform Studies, C. 35, S. 2, 1983, s. 115 - 126.; Trevor Robert Bryce, The Kingdom of the Hittites, Oxford University Press, Oxford 2005, s. 100 - 101.; Nermin Atila, "Hitit Devleti'nde Güvenlik Algısı", Tarih Araştırmaları Dergisi, C. 37, S. 64, 2018, s. 161 - 190.
} 
kardeşi vardl. Onlara evler tahsis etti: "Gitsinler, otursunlar, yesinler, içsinler. Onlara kimse kötülük yapmasın!” Ben diyorum ki: “Onlar bana kötülük yaptı, ben onlara kötülük yapmayacă̆ım!” (Ben) Teleipinu babamın tahtına oturunca, Haşşuwa'ya karşı savaşa gittim ve Haşşuwa'yı imha ettim. (...) Kral ailesinde kan (dökmeler) çoğaldı. (...) Bu andan itibaren Hattuşa'da kral ailesinin bir çocuğuna hiç kimse kötülük yapmayacak, ona bıçak çekmeyecek! Yalnız öndeki (en büyük erkek) çocuk, prens, kral olsun! Eğer öndeki (bir prens) yok ise, kim ikinci stradaki oğul ise, kral o olsun! Ĕger varis (olacak) bir prens yok ise, hangi klz çocuk öndeki ise, ona bir içgüveysi alsınlar, o kral olsun! Gelecekte kim benden sonra kral olursa, kardeşleri, oğulları, hisımlarl, akrabaları ve askerleri birlik olsunlar!" 12

Telepinu'nun dönemi Hitit Krallığı için bir istikrar döneminin başlangıcı sayılmaktadır. Kendisinden önce tahtı gasp ederek iktidara geçen zayıf krallar, Hititlerin özellikle Kuzey Suriye'deki hakimiyetinin son bulmasına neden olurken; iç karışıklıklar, krallığı yıkılmanın eşiğine getirmiştir. Metinden anlaşıldığı kadarıyla Telepinu da Hitit krallık ailesine sonradan katılan bir birey olup süregiden taht mücadelesinde hayatını kaybedecekti. Fakat Huzziya'nın kendisini öldüreceğini anlayan Telepinu, daha hızlı davranıp Huzziya’yı saf dışı bırakmayı başarmıştır. Telepinu, tahta çıktığı zaman önceki kralların yaptığı gibi kendi iktidarına karşı çıkan diğer hanedan ailesi mensuplarını öldürmemiş onları yönetimden uzaklaştırmış ama hayatlarını bağışlamıştır. Sonrasında Hitit tarihinde ilk defa tahta çıkışı sistemleştirecek bir adım atmıştır. Telepinu'nun metnin yazdırılışının temel gerekçesi olan bu sistemleştirme, kralın ölümünden sonra en büyük oğlun tahta çıkmasını eğer oğul yoksa en büyük kızın eşinin kral olmasını içermektedir. Bu sistemin daha önce Hititlerde kullanıldığı iddia edilmesine rağmen sözlü bir gelenek olan bu durumun Telepinu tarafından yazılı bir kanun haline getirilmiş olduğu düşünülmektedir. Telepinu bu kanun ile kraliyetin devamlılığını garanti altına almaya çalışmış olmasına rağmen Hititlerdeki taht mücadelelerinin devam ettiği görülmektedir. ${ }^{13}$

“(Siz) tanrllar, efendilerim, Hatti ülkesinde salgın oldu. (...) Yirmi yıldan beri Hatti ülkesi çok (sayıda kayıplarla) ölüme sürüklendiğinden aklıma Tuthaliya'nın oğlu genç Tuthaliya konusu geldi. Genç Tuthaliya Hatti ülkesinin efendisi iken ona Hattusa'nın prensleri, komutanları, binbaşıları, subayları, (önde gelenleri), askerlerinin ve araba savaşçılarının hepsi onun üstüne (biat için) yemin ettiler. Babam da onun üstüne yemin etti. Babam (genç) Tuthaliya'yı sıkıştırınca, Hattusa'nın prensleri, komutanlarl, binbaşılar, bütün subaylar babamın yanında oldular. (...) Onlar Tuthaliya'yı öldürdüler. Ayrıca kardeşlerini (...) de öldürdüler. Babam, Tuthaliya'nın kanı yüzünden öldü. Babamdan yana olan prensler, komutanlar, binbaşılar, subaylar, onlar da o nedenle öldü." "14

II. Murşili'nin dualarından alınmış olan metinde, Kral, ülkesini kasıp kavuran salgın hastalığın, babasının, tahta geçmek için Kral Tuthaliya ve kardeşlerini öldürmesinin bir cezası olarak tanrılar tarafından gönderildiğine inandığı anlatılmaktadır. Bu anlatıya göre kraliyet ailesinden birinin kanının dökülmesinin tanrısal bir cezaya neden olacağına dair inanış ortaya

\footnotetext{
12 Alp, age. s. 61.

${ }^{13}$ Amelie Kuhrt, Eski Çă̆'da Yakındoğu (M.Ö. 3000 - 330) Cilt: 1, Çev. Dilek Şendil, İș Bankası Kültür Yayınları, İstanbul 1995, s. 320 - 325.; Petra Goedegebuure, "The Proclamation of Telipinu", The Ancient Near East: Historical Sources in Translation, Ed. Mark W. Chavalas, Wiley-Blackwell, Malden 2006, s. 228 - 235.; Siim Mõttus, The Edict of Telepinu and Hittite Royal Succession, Yayınlanmamış Doktora Tezi, 2018. University of Tartu, s. 61 - 70.; John Van Seters, In Search of History: Historiography in The Ancient World And The Origins Of Biblical History, Eisenbrauns, Winona Lake, Indiana 1997, s. 115 - 120.; Robert S. Hardy, "The Old Hittite Kingdom: A Political History”, The American Journal of Semitic Languages and Literatures, C. 58, S. 2, 1941, s. 177 - 216. Gary Beckman, "Inheritance and Royal Succession Among the Hittites", Assyriological Studies No: 23, The Oriental Institute of the University of Chicago Press, Chicago 1983, s. 13 - 31.

${ }^{14}$ Alp, age. s. $128-129$.
} 
çıkmaktadır. Bu inanış, krala karşı oluşacak ayaklanmayı tanrıların istemediği ve tanrısal olarak cezalandırılacağ ${ }_{1}$ kabullenişine dayanmış olmalıdır. ${ }^{15}$

\section{Mısır Tahta Geçiş Sistemi}

Mısır, Nil Nehri'nin oluşturduğu kendine has coğrafyası ile tarımsal yaşamın oldukça erken dönemlerde başladığı bir bölgedir. Nil Nehri kıyısında oluşmaya başlayan tarım köyleri zamanla şehirlere dönüşürken, her şehrin kendine ait yöneticisi ve özgün tanrıları ortaya çıkmıştır. Zaman içerisinde bu şehirlerin yöneticileri, diğerlerine galip gelerek hüküm sürdüğü toprakları genişletme mücadelesine başlamıştır. Yüzyıllar süren bu mücadeleden sonra yaklaşık MÖ. 3100'lü yıllarda Narmer olarak isimlendirilen bir yönetici tüm Mısır'1 bir idare altında toplayarak, Mısır'ın ilk büyük kralı olmuştur. ${ }^{16}$ Oldukça erken bir dönemde merkezi krallık ile yönetilmeye başlayan Mısır'ın çöller ve Akdeniz ile çevrili izole coğrafyasında binyıllar boyu ardı ardına gelen onlarca sülaleye mensup Mısır kralları, gelişmiş bir kraliyet kültürü ile tahta geçiş sistemi oluşturmuşlardır. Bu kraliyet kültürü ve tahta geçiş sisteminin dahi engelleyemediği taht mücadeleleri, Misır'ın tarihinin şekillenmesinde büyük öneme sahiptir. Binyıllar boyunca Mısır'da birçok taht mücadelesi yaşanmış olmasına rağmen Hitit Krallığı'nın kronolojisini ile çağdaş olan XVIII. ve XIX. sülaleler dönemindeki olaylara çalışmamızda yer verilmiştir.

Hitit krallığının kurulmaya başladığı dönemlerde (MÖ. 1600’lerde) Mısır'ın bir kısmı Hiksos toplumunun işgali altındaydı. Hiksoslar, Doğu Akdeniz kıyısı boyunca güneye ilerleyerek Mısır'ın Delta bölgesini işgal etmiş ve Avaris kentini kraliyet şehri yaparak kendi krallıklarını oluşturmuş̧lardır. Yaşadıkları Delta bölgesinde, Mısır'ın yerel kültürünü benimseyen ve tanrılarına tapmaya başlayan Hiksosların kralları ile güneydeki Vadi bölgesinde yaşayan Mısır kralları arasında uzun süreli mücadeleler gerçekleşmiştir. Temelde bir taht mücadelesi olmayan bu savaşlar, parçalanan Mısır'ı bir yönetim altında toplama çabasıdır. On sekizinci sülalenin de kurucusu sayılan Ahmose, Hiksosları mağlup edip Mısır'ın parçalanmışlığına son vermiştir. ${ }^{17}$ Ahmose, Misır'ın gerek dişardan gelen istilacılar gerekse bölgesel yöneticilerin ayaklanmaları ile parçalanmaması için kalabalık bir ordu ve merkezi bir bürokrasi sınıfı oluştururken güçlü bir kraliyet bilinci de geliştirmiştir. Bu kraliyet bilinci, temelde kralın ve onun soyundan gelenlerin tanrılık iddiasına dayanmasına rağmen özelde kralı ve ailesini kesin bir çizgi ile yönetilenlerden ayırmaktaydı. Bu ayrımın sağlanabilmesi için de kraliyet ailesine dışarıdan tüm erişimin kesilmesi gerekmiştir. Taht kavgalarının önüne geçmek ve kraliyet ailesine erişimi engellemek için, Mısır toplumunda bir tabu olan aile içi evliğe, kraliyet ailesi içerisinde izin verilmiş ve hatta bazı durumlarda zorunlu tutulmuştur. Mısır'da kraliyet ailesi içerisindeki evliliklerin

\footnotetext{
${ }^{15}$ M. A. Dinçol, “Ashella Ritüeli (CTH 394) ve Hititlerde Salgın Hastalıklara Karşı Yapılan Majik İşlemlere Toplu Bir Bakıș”, Belleten, C. 49, S.193, Ankara 1985, s. 1 - 40.; Itamar Singer, Hittite Prayers, Brill, Leiden 2002, s. 57 72.; Özlem Sir Gavaz, "Hitit İmparatorluk Devri Krallarından I. Šuppiluliuma Döneminde Anadolu”, Hitit Üniversitesi Sosyal Bilimler Enstitüsü Dergisi, C.1, S. 1, 2008, s. 21 - 39.; Philip Norrie, A History of Disease in Ancient Times: More Lethal than War, Springer, New York 2016, s. 51 - 52.; Aysel Kömürcü, Hitit Krallığı'nda Veba Salgını ve Etkileri (M.Ö. II. Binyılın İlk Yarısı), Yayınlanmamış Yüksek Lisans Tezi, Afyon Kocatepe Üniversitesi, 2019, s. 49 -58 .

16 T. A. H. Wilkinson, "What a King is This: Narmer and the Concept of the Ruler", The Journal of Egyptian Archaeology, S. 86, 2000, s. 23 - 32.; T. C. Heagy, "Who was Menes?", Archéo-Nil, S. 24, 2014, s. 59 - 92 .; David Wengrow, The Archaeology of Early Egypt: Social Transformations in North-East Africa, c. 10.000 to 2.650 BC, Cambridge University Press, Cambridge 2006, s. $41-42$.

${ }^{17}$ John Van Seters, The Hyksos: A New Investigation, Wipf and Stock Publishers, Oregon 2010, s. 97 - 126.; A. H. Sayce, "The Hyksos in Egypt", The Biblical World, C. 21 S. 5, 1903, s. 347 - 355.; E. A. Speiser, "Ethnic Movements in the Near East in the Second Millennium BC: The Hurrians and Their Connections with the Habiru and the Hyksos", The Annual of the American Schools of Oriental Research, S. 13, 1931, s. 13 - 54.; D. B. Redford, "The Hyksos Invasion in History and Tradition", Orientalia, C. 39, S. 1, 1970, s. 1 - 51.; Afet İnan, Eski Misır Tarih ve Medeniyeti, Türk Tarih Kurumu Yayınları, Ankara 1987, s. 91.; Torgny Säve-Söderbergh, "The Hyksos Rule in Egypt" The Journal of Egyptian Archaeology, C. 37, S. 1, 1951, s. 53 - 71.
} 
gerçekleşmesinin ne kadar eskiye uzandığı bilinmese de özellikle XVIII. ve XIX. sülaleler döneminde kraliyetin bekası için bu durum gelenekselleşmiştir. ${ }^{18}$

Ahmose döneminden itibaren iç istikrarı yakalayan Mısır, güneyde Nübye'ye kuzeyde Firat Nehri'ne uzanan askeri ve ticari seferlere başlamıștır. Ahmose'nin ardılları olan I. Amenofis, I. Tutmosis ve II. Tutmosis dönemlerinde de bu gelişme sürdürülmüştür. Bu dönemde bir çatışmaya dönüşmeyen taht mücadelesi I. Tutmosis'in kızı olan Hatşepsut'un üvey kardeşi II. Tutmosis ile evlenip bir kraliçe olarak ülkeyi yönetmeye başlamasıdır. Hatşepsut'un II. Tutmosis ile olan evliliğinden bir erkek çocuk dünyaya gelmemesine rağmen II. Tutmosis'in diğer evliliğinden olan oğlu III. Tutmosis, babasının ölümü üzerine tahta geçmiştir. III. Tutmosis büyüdükçe kendisine naiplik yapan Hatşepsut ile aralarında güç mücadelesi başlamıştır. $\mathrm{Bu}$ iktidar mücadelesinde III. Tutmosis'in Hatşepsut'un ölümüne kadar başarı sağlayamadığı anlaşılmaktadır. III. Tutmosis'den sonra Misır tahtına geçen II. Amenofis ve IV. Tutmosis dönemleri de istikrar ve zenginlik yılları olmuştur. ${ }^{19}$

Bu dönemde Ön Asya'nın büyük güçleri olan Mısır, Hitit, Babil ve Mitanni krallıkları arasında yoğun bir diplomatik ilişki ile kraliyet aileleri arasında evlilikler yaygınlaşmıştır. Bu durumun temelinde kendilerini tanrısal soya bağlayan kraliyet ailelerinin birbirleri ile evlenmelerinin kanlarının kutsallığına zarar vermeyeceğine olan inancın yer aldığ düşünülmektedir. Ayrıca kendi ülkesinden oldukça uzaklarda bulunan bu prenseslerin herhangi bir taht mücadelesine girmesi pek mümkün gözükmemekteydi. Kraliyet aileleri arasında yapılan bu evliliklerden biri IV. Tutmosis'in ardilı olan Misır Kralı III. Amenofis ile Mitanni kralının kızı arasında gerçekleşmiştir. Böylece birden fazla evlilik yapan Mısır kralları, tahtı bırakacakları erkek evlat konusunda sıkıntı çekmezken anneleri birbirinden farklı bu prenslerin mücadeleleri kaçınılmaz olmuştur. ${ }^{20}$ Fakat Mısır krallarının bu dönemde kendisinden sonra tahta geçmesini planladığı veliahdına ordu komutanlığı gibi yüksek görevler verdiği bilinmektedir. Bunun yanı sıra en büyük kızını da Amon'un baş rahibesi yaparak siyasi alandan uzak tutuğu görülmektedir.

Mısır'da süregelen düzenin devamlılığını bozan durum ise Akhenaton'un geleneksel Misır tanrıları yerine tek tanrılı bir inanç yaratmak için giriştiği büyük dönüşümdür. $\mathrm{Bu}$ dönüşüm esnasında Kral Akhenaton, Amon'a bağlı olan ruhban sınıfı mensuplarının etkisinden kurtulmak için eski başkentini terk edip kendisine Amarna kentini inşa ettirmiştir. Siyasi otorite ile Amon'a bağlı dini otoriteyi birbirinden ayırmayı amaçlayan bu girişim, Amon'a bağlı olan ruhban sinıfı mensuplarında büyük bir öfkeye neden olmuşsa da Akhenaton'a karşı doğrudan bir saldırıya dönüşmemiştir. $\mathrm{Bu}$ durumun temelinde ise süregelen Tanrı - Kral anlayışı bulunmaktadır. Akhenaton'un gözdesi ve kraliçesi olan Nefertiti'den erkek evladı olmaması üzerine evlendiği düşünülen bir diğer eşi olan Kiya'da olan oğlu Tutankaton tahta geçmiştir. Tahta çıktıktan sonra

\footnotetext{
${ }^{18}$ Russell Middleton, "Brother-sister and Father-daughter Marriage in Ancient Egypt" American Sociological Review, C. 27, S. 5, 1962, s. 603 - 611.; T. D. Allen, The Ancient Egyptian Family: Kinship and Social Structure, Routledge, Abingdon 2008, s. 28 - 55.; Keith Hopkins, "Brother-sister Marriage in Roman Egypt", Comparative Studies in Society and History, C. 22, S. 3, 1980, s. $303-354$.

${ }^{19}$ Emily Teeter, "Museum Review: Hatshepsut and Her World", American Journal of Archaeology, C. 110, S. 4, 2006, s. 649 - 653.; Edward L. Margetts, "The Masculine Character Of Hatshepsut, Queen Of Egypt", Bulletin of the History of Medicine, S. 25, 1951, s. 559 - 562.; Pamela Dell, Hatshepsut: Egypt's First Female Pharaoh, Compass Point Books, Minneapolis 2008.; Kristina Hilliard - Kate Wurtzel, "Power and Gender in Ancient Egypt: The Case of Hatshepsut", Art Education, C. 62, S. 3, 2009, s. 25 - 31.; Pearce Paul Creasman, "Hatshepsut and the Politics of Punt", The African Archaeological Review, C. 31, S. 3, 2014, s. 395 - 405.

${ }^{20}$ H. J. Marsman, Women in Ugarit and Israel: Their Social and Religious Position in the Context of the Ancient Near East, Brill Press, Leiden 2003, s. 384.; Ahmet Ünal ve, K. S. Girginer, Kilikya-Çukurova: IIlk Çağlardan Osmanlılar Dönemi'ne Kadar Kilikya'da Tarihi Coğrafya, Tarih ve Arkeoloji, Homer Kitabevi, İstanbul 2007, s. 102.; K. A. Kitchen, Suppiluliuma and the Amarna Pharaohs: A Study in Relative Chronology, Liverpool University Press, Liverpool 1962, s. 33.
} 
ismini Tutankamon olarak değiştiren genç kralın sahip olduğu fiziksel problemlerinin aile içi evlilikten kaynaklanmış olduğu düşünülmektedir. Kraliyet ailesinin son erkek üyesi olan Tutankamon da babası Akhenaton'un Nefertiti'den olan kızı Ankhesenamon ile evlenmiştir. Bu dönemde kraliyet ailesi içerisinde yapılan evliliklerde çocuk doğmadığı, doğan çocukların ise küçük yaşta öldüğü ve fiziksel rahatsızlıklarının olduğu bilinmektedir. Tutankamon ve Ankhesenamon arasındaki evlilikten de bir çocuk doğmamıştır. Kraliyet ailesine dışarıdan katılımı önlemek için alınan aile içi evlilik tedbiri bir süre taht mücadelelerini önlemiş ve kraliyetin devamlılığını sağlamışsa da veliaht üretememe sorununu beraberinde getirmiştir. Tutankamon'un tahta geçtikten bir süre sonra on dokuz yaşında ölümü üzerine Mısır kraliyet ailesinden tahta çıkacak kimse kalmamıştır. ${ }^{21}$

\begin{abstract}
“Babam (I. Şuppiluliuma) Kargamış ülkesinde iken Lupakki ve Tarhunta-zalma'yı Anka ülkesinin içlerine gönderdi. Onlar saldırdıkları topraklardan köleler, sığırlar ve koyunlarla babamın yanına geri geldiler. Fakat Misır insanları Amka'ya yapılan saldırıy duyduklarında korktular. Ayrica, onların (Misırlıların) efendisi (kralı) Nibhururiya (Tutankamon) öldü, bu nedenle, Misır kraliçesi Dahamunzu (Ankhesenamon) bir elçi gönderdi ve şöyle yazmıştı: Kocam öldü, bir oğlum da yok. Fakat söylediklerine göre senin çok oğlun var. Ĕger senin oğullarından birini sen bana gönderirsen onu kendime koca yapacağım. (Böylece) asla bir hizmetçimi seçip onu kocam yapmam gerekmeyecek (...) korkuyorum." 22
\end{abstract}

Volume 12

Issue 5

October

2020

Metin, Tutankamon'un eşi ve Akhenaton'un kızlarından biri olan Ankhesenamon, tahta çıkacak bir veliahdın yokluğu üzerine Hitit Kralı I. Şuppiluliuma'ya yazdığı, çaresizliğini anlatan mektubundan alınmıştır. Kraliçe Ankhesenamon, soyunun devamlılığını sağlayabilmek için kraldan bir oğlu ile evlilik yapmak isteğini belirtmektedir. Misır devlet geleneği açısından kabul edilemez olan bu duruma çaresizliğinin yol açtığını da belirtmektedir. Bu isteğin karşısında I. Şuppiluliuma, araştırma için bir heyet göndermiş ve bu heyetin olumlu görüşü ve Misır kraliçesinin ikinci mektubu üzerine oğlunu kraliyet evliliğinin gerçekleşmesi için Mısır'a uğurlamıştır. Fakat Hitit prensi Zannanza, Mısır'a varamadan ölmüş veya öldürülmüştür. ${ }^{23}$

Tutankamon'un ölümünden sonra Misır'ı yönetecek bir kral adayı kalmayınca eşi Ankhesenamon bir taraftan Hitit Kralı I. Şuppiluliuma'dan yardım isterken diğer taraftan Mısır'ın en üst düzey görevlileri olan Horemheb, Ay ve Maya ile kapalı kapılar ardında mücadele vermekteydi. Zannanza'nın da ölümü üzerine bir çıkış yolu kalmayan Ankhesenamon'un bir kenara çekilmesi ile kraliyet ailesinden olmamasına rağmen kraliyete en yakın kişi olan Ay'ın Mısır tahtına çıktığını görmekteyiz. Ay'ın kim olduğu konusunda birçok tartışma bulunmasına rağmen onun III. Amenhotep'in kayınbiraderi olduğu görüşü ağır basmaktadır. Bu görüş doğru kabul edildiğinde Tutankamon'dan iki veya üç nesil büyük olması gereken Ay'ın yaşının oldukça ilerlemiş olduğu kabul edilmelidir. Bu sebepten Ay’ın dört yıl tahtta kaldıktan sonra öldüğü düşünülmektedir. Mısır kralı olan Ay’ın Tiy isimli bir eşi olsa dahi bunların tahtta veliaht

${ }^{21}$ J. K. Hoffmeier, Akhenaten and the Origins of Monotheism, Oxford University Press, Oxford 2015, s. 136 - 164.; F. J. Giles, "Amenhotpe, Ikhnaton and the Succession", Aegyptus, C. 32, S. 2, 1952, s. 293 - 310.; E. A. W. Budge, Tutankhamen: Amenism, Atenism, and Egyptian Monotheism: with Hieroglyphic Texts of Hymns to Amen and Aten, Dover, Mineola 1991, s. 55 - 110.; Mario Liverani, "The Great Powers' Club" Amarna Diplomacy: The Beginnings of International Relations, Ed. Raymond Cohen, Raymond Westbrook, The Johns Hopkins University Press, Baltimore 2002, s. 15 - 27.

${ }^{22}$ H. G. Güterbock, "The Deeds of Suppiluliuma as Told by his Son, Mursili II (No:3)" Journal of Cuneiform Studies, C. 10, S. 3, 1956, s. $75-98$.

${ }^{23}$ Aidan Dodson, Monarchs of the Nile, The American University in Cairo Press, Cairo 2000, s. 113 - 114.; E. H. Cline, MÖ. 1177 Medeniyetin Çöktüğü Yll, Çev: Ayşegül Kuglin, Bilge Kültür Sanat, 2018, s. 81 - 87.; J. L. McLaughlin, The Ancient Near East: An Essential Guide, Abingdon Press, Nashville 2012, s. 52.; Bryce, a.g.e., 195 - 198.; Jan Assmann, The Mind of Egypt: History and Meaning in the Time of the Pharaohs, Harvard University Press, Harvard 2003, s. $251-255$. 
bırakacak bir oğullarını olmadığı da bilinmektedir. Bu dönemde yaşanan taht mücadelesinde rol alan bir diğer kişi ise Maya veya May'dır. Akhenaton ve Tutankamon dönemlerinde hazinenin ve yapı işlerinin gözetmeni olan Maya, hem Ay'ın hem de Horemheb'in dönemlerinde güçlü bir saray görevlisi olarak karşımıza çıkmaktadır. Ay'dan sonra tahta çıkan ve kraliyet ailesi ile hiçbir kan bağının olmadığı bilinen Horemheb'in krallığından önceki dönem hakkında bilgilerimiz oldukça sınırlıdır. ${ }^{24}$

"Sana övgüler olsun (Tanrl) Ra, gerçeğin efendisi, yüce tanrl, Heliopolis (şehrinin) hakimi, (Tanrı Ra), ordunun başkomutanı olan, muzaffer, Horemheb'e şanslı bir hayat, sonsuzluk, gökyüzünde zafer, yeryüzünde iyilik versin. "25

Akhenaton dönemine ait yazıtın bir bölümünü oluşturan metin, ordu komutanı olan Horemheb için iyi dilekler içermektedir. Metinden, bu dönemde, yeni dini için mücadele veren Akhenaton'un ülkesinin sınırlarını savunma görevini Horemheb'e bırakmış olduğu anlaşılmaktadır. Böylece etkinliği sadece Amarna kenti ile sınırlı kalmış olan Akhenaton'un aksine Horemheb tüm ülkede nüfuz sahibi olmayı başarmıştır. Akhenaton'dan sonra tahta çıkan Tutankamon yaşça küçük ve sonrasında kral olan Ay'da oldukça yaşlı olmasından dolayı, Horemheb, sahip olduğu askeri güç ile siyasi nüfuzunu daha da artırmıştır. ${ }^{26}$

\begin{abstract}
“Övgüler sana olsun (...) Osiris, sonsuzluğun hükümdarl (...) kralın vekili, iki ülkenin (Aşăg ve Yukarı Misır'ın) başkanı, muzaffer Horemheb. O şöyle dedi: "Saygı sana (...) Abidos'un ortasındaki Osiris, majestelerinin güzelliğini hayranlıkla görmek için sana iki elimi uzattım”" (...) kralın tüm ülkedeki vekili, genel idareci, muzaffer, Horemheb. " 27
\end{abstract}

Horemheb'in Tanrı Osiris'e duasını içeren metin, Horemheb'in sahip olduğu kapsayıcı unvanları göstermesi açısından önemlidir. Metinde, kralın her konuda vekili olan Horemheb'in iki ülkenin de yöneticisi olduğu belirtilmiştir. Mısır'da merkezi yönetim sağlandıktan sonra bile idari bir ayrım olarak Așağı ve Yukarı Mısır'a farklı vezirler, hakimler ve komutanlar atanmıștır. Horemheb bu geleneği sona erdirmiş ve metinde de görüldüğü üzere "kralın tüm ülkedeki vekili" unvanını kullanmaya başlamıştır. Horemheb sahip olduğu bu güce rağmen Akhenaton ve Tutankamon'a karşı doğrudan bir isyan girişiminde bulunmamıştır. Bu durumun temelinde Mısır'daki Tanrı - Kral anlayışı ve güçlü krallık bilincinin bulunduğu düşünülmektedir.

“Aşağı ve Yukarı Mısır'ın Kralı (Zeserkheprure-Setepnere) Horemheb’in krallı̆̆ının üçüncü yılında, efendi, babası Amon'a ekmek sunduktan sonra, sarayında tatmin edici yaşama benzer güneş gibi göründü. Altın Evden çıkarken, (halkının) coşkusu tüm topraklar üzerinden geçerek sevinç içerisinde göklere ulaştı." 28

Horemheb'in kendisini kral ilan edişinden sonra yazdırılmış olan metinde, Mısır krallarının dini ritüellerinin birinin Horemheb tarafından gerçekleştirildiğini görmekteyiz. Kraliyet ailesinden kalan kimse olmayınca ülkenin en güçlü memuru olan Horemheb'in Mısır kralı oluşu beklenen bir gelişme olmalıdır. Metinde de görüldüğü üzere Horemheb'in krallığı yönetilenler

${ }^{24}$ Trevor Robert Bryce, "The Death of Niphururiya and its Aftermath", The Journal of Egyptian Archaeology, C. 76, S.1, 1990, s. 97 - 105.; Jacobus van Dijk, "New Evidence on the Length of the Reign of Horemheb", Journal of the American Research Center in Egypt, S. 44, 2008, s. 193 - 200.; Allan K. Philips, "Horemheb, Founder of the XIXth Dynasty?", Orientalia, C. 46, S. 1, 1977, s. 116 - 121.; Jacobus van Dijk, "Horemheb and the Struggle for the Throne of Tutankhamun", Bulletin of the Australian Centre for Egyptology, S. 7,1996, s. 29 - 42.

${ }^{25}$ J. H. Breasted, Ancient Records of Egypt: Historical Documents from the Earliest Times to the Persian Conquest (Vol. 3), University of Chicago Press, Chicago 1906, s. 4.

${ }^{26}$ Percy E. Newberry, "King Ay, the Successor of Tut'ankhamon”, The Journal of Egyptian Archaeology, C. 18, S. 1, 1932, s. 50 - 52.; Nozomu Kawai, "Ay Versus Horemheb: The Political Situation in the Late Eighteenth Dynasty Revisited" Journal of Egyptian History, C. 3, S. 2, 2010, s. 261 - 292.

${ }^{27}$ Breasted, age, s. 10.

${ }^{28}$ Breasted, age, s. 34. 
tarafından coşku ile kutlanmaktadır. Çünkü ülkede baş gösteren siyasi istikrarsızlığın ve yetersiz kralların oluşturduğu istenmeyen kaos, güçlü bir kişiliğe sahip olan Horemheb'in tahta geçişi ile sonlanmıştır.

\begin{abstract}
"Efendiniz, (...) her şehirdeki vatandaşların yargı işlerini görmek için, resmi görevlileri, tapınakların görevlilerini, bu toprakların mahkemelerinin memurlarını atadı. İște o, (kral) efendiniz Misır'in kanunudur. O, Ra'nın tahtına oturduğundan beri yaşayanların hayatların daha güzel hale getirmek için Mısır'ın kanunlarını belirledi. Isşte bütün bir ülkeye yetkili memurlar atand,, (onları) bütün şehirlerde rütbelerine göre yerleştirdi. "29
\end{abstract}

Horemheb, krallığını ilan ettikten sonra Mısır'daki düzeni tekrar tesis etmeye odaklanmıştır. Horemheb'e ait olan yazıttan alınmış olan metinde görüldügü üzere Tanrı Ra'nın tahtına oturduktan sonra ülkede yaşayanların hayatlarını daha güzel hale getirmeye çalıştığını bizzat kendisi belirtmektedir. Misır'a yeniden düzen getiren Horemheb'in kendisinden sonra tahta çıkacak bir oğlu kalmadığı bilinmektedir. Bunun üzerine Horemheb, bir tahta geçiş yöntemi olan veliaht belirleme sistemini kullanarak son dönemlerinde veziri olan eski komutanlarından I. Ramses'i veliaht tayin etmiştir. Horemheb'in ölümü ve I. Ramses'in tahta çıkması ile XVIII. sülale sona ermiş ve XIX. sülale dönemi başlamıştır. ${ }^{30}$

I. Ramses'in yaklaşık iki yıl süren krallığı döneminde birkaç küçük inşa faaliyeti dışında bir gelişme görülmemiştir. Ölümünden sonra ise babası ile ortak krallık yapan I. Seti tahta geçmiştir. I. Seti, ülkede sağladığı iç istikrardan sonra Mısır'ın daha önce Doğu Akdeniz kıyılarında kaybettiği toprakları geri alma mücadelesine girişmiştir. I. Seti'nin Kadeş'i Hititlerden geri almayı başardığı ve Mısır'ın etkin dış politikasını sürdürmeye çalıştığı bilinmektedir. I. Seti döneminde başlayan genişleme politikası oğlu II. Ramses döneminde hız kazanmış ve Doğu Akdeniz kıyılarındaki bağımsız şehir devletleri üzerinde defalarca seferler düzenlenmiştir. Hititlerin güç kaybettiği, Mısır'ın yeni topraklar ele geçirdiği bu dönemin en önemli siyasi gelişmesi ise Kadeş antlaşması olarak isimlendirilen barışın yapılmasıdır. ${ }^{31}$ Mısır'ın en büyük rakibi olan Hitit ile karşılıklı saldırmazlığın kabulünde ise bu dönemde Mısır kıyılarına saldıran Sherden toplumunun varlığı etkili olmuş olmalıdır. Yaklaşık otuz beş yıl tahtta kalan II. Ramses'in sahip olduğu otuz erkek çocuğundan biri olan Merneptah, babasının sağlığında ordu komutanlığı gibi yüksek bir görevde bulunmuş sonrasında ise veliaht ilan edilmiştir. Merneptah döneminde Deniz Kavimleri Göçlerine katılan kavimlerden olan Ekwesh, Teresh, Lukka, Sherden ve Shekelesh toplumlarının Mısır'a saldırıları başlamıştır. Merneptah bu toplumların ilerleyişini durdurmak için uzun süre mücadele vermiştir. Muhtemelen Merneptah'ın ölümünden sonra başlayan taht mücadelesi döneminde ise bu toplumların Mısır'a ilerleyişi hız kazanmıştır. ${ }^{32}$

\footnotetext{
${ }^{29}$ Breasted, age, s. 32.

${ }^{30}$ Aidan Dodson, Amarna Sunset: Nefertiti, Tutankhamun, Ay, Horemheb, and the Egyptian Counter-Reformation, Oxford University Press, Oxford 2009, s. 112 - 129.; J. R. Harris, "How Long Was the Reign of Horemheb?", The Journal of Egyptian Archaeology, S. 54, 1968, s. 95 - 99.; Rosalie F. Baker - Charles F. Baker, Ancient Egyptians: People of the Pyramids, Oxford University Press, Oxford 2001, s. 143 - 144.

${ }^{31}$ Hans Goedicke, "Considerations on the Battle of Kadesh", The Journal of Egyptian Archaeology, C. 52, S. 1, 1966, s. 71 - 80.; Claire Epstein, "That Wretched Enemy of Kadesh”, Journal of Near Eastern Studies, C. 22, S. 4, 1963, s. 242 - 246.; Mark Healy, The Warrior Pharaoh: Ramses II and the Battle of Qadesh, Osprey, Oxford 1993, s. 19 82.; Lanny Bell, "Conflict and Reconciliation in the Ancient Middle East: The Clash of Egyptian and Hittite Chariots in Syria, and the World's First Peace Treaty between "Superpowers", War and Peace in the Ancient World, Ed. K. A. Raaflaub, Wiley-Blackwell, Malden 2007, s. 98 - 120.

32 David O'Connor, "The Sea People and Egyptian Sources”, The Sea Peoples and Their World: A Reassessment, Ed. E. D. Oren, University of Pennsylvania Press, Pennsylvania 2000, s. 85 - 102.; G. A. Wainweight, "Some Sea-Peoples and Others in the Hittite Archives", The Journal of Egyptian Archaeology, C. 25, S. 1, 1939, s. 148 - 153.; Assaf Yasur-Landau, The Philistines and Aegean Migration at the end of the Late Bronze Age, Cambridge University Press,
} 
Merneptah'dan sonra Misır'ı yöneten Amenmeses'nin kim olduğu ve nasıl tahta çıktığı konusunda bir görüş birliği bulunmamaktadır. Bir görüşe göre Amenmeses'nin II. Ramses'in birçok oğlundan biri olduğu ve Merneptah'ı devirerek iktidarı devraldığını düşünülmektedir. Bir diğer görüş ise Amenmeses'nin Merneptah'ın oğlu olduğu, Kuş valisi iken ayaklandığ 1 ve Mısır'ın bir kısmını yönettiği iddiasına dayanmaktadır. Bu görüşlerden hangisinin doğru olduğu tam olarak bilinmese de Amenmeses'nin bir taht mücadelesinin sonucunda Misır'ın bir kısmının yönetimini ele geçirdiği üzerinde görüş birliği vardır. Amenmeses'nin kısa süren iktidarı döneminde siyasi ve askeri önemli bir gelişmenin yaşanmamasının temelinde de bu taht mücadelesinin yansımalarının devam etmesi olduğu düşünülmektedir. ${ }^{33}$ Amenmesse ile aynı dönemde krallık yaptı̆ğ ve ölümünden sonra Mısır'ın tek yöneticisi olduğu bilinen II. Seti'nin ise Merneptah'ın bir diğer oğlu olduğu iddia edilmektedir. II. Seti'nin, Amenmesse'nin ölümünden sonra hüküm sürdüğü ve daha önce Amenmesse'nin kontrolündeki Yukarı Mısır ve Teb şehrini ele geçirdiği bilinmektedir. II. Seti'nin altı yıl kadar süren tek krallık dönemi, ölümü ile sona ererken yerine henüz çocuk yaşta olan Siptah, geçmiştir. Öldüğünde on altı yaşında olan Siptah'ın sekiz yıl sürdüğü düşünülen krallığı döneminde Mısır'ın esas yöneticisinin II. Seti'nin eşi olan Kraliçe Tausret olduğu bilinmektedir. Fakat bu dönemde Kraliçe Tausret "Kralın Annesi” unvanını kullanmamıştır. Bu durum, Siptah'ın II. Seti'nin oğlu olmadığını göstermediği gibi Siptah'ın kraliyete nasıl bir soy ile bağlandığını bilmemizi de imkansız hale getirmektedir. Siptah'ın ölümü ile de Mısır'ın yönetimi Kraliçe Tausret'e kalmıştır. ${ }^{34}$ Merneptah'ın ölümü ile başlayıp XIX. sülalenin yıkılmasına kadar geçen süre Mısır için bir karışıklık dönemi olmuştur. Bu dönemde Amenmesse ve Siptah'ın gayri meşru krallar olduğu bilinmektedir. Bu iki kral adayının isyanları ile Mısır'ın merkezi yönetiminin zayıfladığı ve yerel yöneticilerin güçlendikleri bilinmektedir. Ayrıca Mısır'ın Doğu Akdeniz'deki ilerleyişi durmuş, Merneptah döneminde Mısır'a istila girişimine başlayan kavimlerin ilerleyişi hızlanmıştır. Hatta bazı Mısır bilimcilere göre bu dönemde merkezi yönetimin güç kaybetmesi Deniz Kavimleri Göçlerine katılan toplumların Mısır'a ilerleyişi için aranan firsatı sağlamıştır. XIX. Sülale'nin çöküşüne dek devam eden dönemdeki eksik bilgilerin temelinde ise bu dönemde birbirlerinin iktidarını kabul etmeyen bu kralların öncekilerin isimlerini yazıtlardan sildirmesi bulunmaktadır. XIX. Sülale'nin son yöneticisi kabul edilen Kraliçe Tausret ise yazıtlarında "Ra'nın kızı" ve "İki ülkenin kraliçesi" unvanlarını kullanmasına rağmen gücünün kraliyet kenti dışına çıkamadığı bilinmektedir. Kraliçe Tausret' in ve XIX. Sülale'nin sonu ise kraliyet ailesinden olmadığı bilinen Setnakht'ın isyanı ile gelmiş, kısa sürede tahtı ele geçirerek ülkeyi tekrar düzene sokmuştur. ${ }^{35}$

"Mısır ülkesi bir yıkıntı haline gelmişti ve insanları haklarını alamıyordu, eski zamanlarda olduğu gibi bir baş ăglz (yöneticinin emredici sözü) yoktu. Mısır ülkesi kasabaların yöneticilerinin ellerindeydi, (bu zamanda) büyük ve küçük (demeden) komşular birbirini öldürüyordu. (...) Fakat artık tanrllar barışın gelmesini; daha önce olduğu gibi ülkedeki

Cambridge 2014, s. 9 - 96; Kuhrt, a.g.e. s. 407 - 411.; Barbara Cifola, "Ramses III and the Sea Peoples: A Structural Analysis of the Medinet Habu Inscriptions" Orientalia, C. 57, S. 3, 1988, s. 275 - 306.

${ }^{33}$ Aidan Dodson, "Messuy, Amada, and Amenmesse", Journal of the American Research Center in Egypt, S. 34, 1997, s. 41 - 48.; Frank J. Yurco, "Was Amenmesse the Viceroy of Kush, Messuwy?", Journal of the American Research Center in Egypt, S. 34, 1997, s. 49 - 56.

${ }^{34}$ Alan Gardiner, "Only One King Siptah and Twosre Not His Wife", The Journal of Egyptian Archaeology, S. 44, 1958, s. 12 - 22.; Cyril Aldred, "The Parentage of King Siptah", The Journal of Egyptian Archaeology, S. 49, 1963, s. 41 - 48.; Gae Callender, "Female Horus: The Life and Reign of Tausret", Tausret: Forgotten Queen and Pharaoh of Egypt, Ed. Richard H. Wilkinson, Oxford University Press, Oxford 2012, s. 25 - 47.; J. Von Beckerath, "Queen Twosre as Guardian of Siptah", The Journal of Egyptian Archaeology, S. 48, 1962, s. 70 - 74.

${ }^{35}$ Vivienne G. Callender, "Queen Tausret and the End of Dynasty 19", Studien zur Altägyptischen Kultur, S. 32, 2004, s. 81 - 104.; Joyce Tyldesley, "Foremost of Women: The Female Pharaohs of Ancient Egypt", Tausret: Forgotten Queen and Pharaoh of Egypt, Ed. Richard H. Wilkinson, Oxford University Press, Oxford 2012, s. 5 - 24.; Alan Gardiner, "The Tomb of Queen Twosre", The Journal of Egyptian Archaeology, S. 40, 1954, s. 40 - 44. 
(insanların) haklarını almalarını istedi. Tüm ülke üzerinde oğulları (olan Setnakht için) büyük tahtı kurdular. O, Userkhaure-setepenre-meryamun, Ra'nın oğlu, Setnakht-meriremeryamun tüm ülkeyi düzene koydu, Mısır ülkesinde olan tüm isyancıları öldürdü, Misır tahtını temizledi, iki ülkenin yöneticisi olarak Atum'un tahtına oturdu. (...) Setnakht, tanrlların tapınakları için önceden sunulduğu gibi kutsal sunular yaptı. "36

III. Ramses döneminde yazılmış olan Harris Papirüsünden alınmış olan metin, Setnakht'ın yıkıntı haline gelmiş olan ülkeyi nasıl yönetimi altında topladığını anlatırken yeni kralın meşruiyetini ispatlama amacıyla da yazılmış olmalıdır. Merneptah döneminden sonra siyasi olarak huzur bulamayan ve gittikçe derinleşen bir kraliyet problemi yaşayan Misır'da beklenen yeni kurtarıcı olan Setnakht toplumun üst kesiminden de destek görerek kısa sürede hakimiyet sağlamıştır. XX. Sülale'nin kurucusu da olan Setnakht, mevcut yönetimde isyan ederek tahta geçen bir kral olmasına rağmen ruhban sınıfının güçlü desteğini almayı başarmıştır. Ruhban sınıfı kısa sürede kabullendiği Setnakht'1, Ra'nın oğlu olarak tanrısal bir soya bağlamıştır. Bundaki en büyük etken ise önceki dönemlerde birbirilerinin kanını dökerek tahta geçen ve ülkeyi sürekli bir iç savaş içine düşürmüş olan seleflerinin ihmal ettikleri tapınakları yeniden ihya etmesi olmalıdır. Setnakht'ın kurmuş oluğu yeni sülale ile barış ve zenginlik çağı başlamış olsa da sonraki dönemlerde de Mısır'da taht mücadeleleri hız kesmeden devam etmiştir. ${ }^{37}$

\section{Sonuç}

Yaşanılan coğrafya ve üretim modeli, toplumların yaşam tarzlarını biçimlendirdiği gibi yönetimlerin de doğasını belirlemiştir. İnsanlık tarihinin büyük çoğunluğu oluşturan ve toplumsallığın önemli parçası olan yönetim, günümüzde bilimin konusu iken eskiçağda inanca bürünmüş dogmatik bir kabulleniştir. Bu kabulleniş, kralın biçimlendirdiğini sandığı fakat onun da genel teamüllün ötesine geçemediği, emir veren ile emir alanın karşılıklı menfaatine dayanan bir işleyiştir. $\mathrm{Bu}$ işleyişin başında olan kral, ülkesindeki her şeyin sahibi olduğu gibi yönettiklerinin üzerinde sınırsız tasarrufu bulunmaktadır. Bu açıdan, ülkede yaşayan herkesin kral olmak gibi bir hayalinin bulunması olağan karşılanmalıdır. Fakat eskiçağdaki tüm inanç sistemleri insanlara öncelikle kralın neden kral, tebaanın da neden tebaa olması gerektiğini kabullendirmeye çalışmıştır. Bu kabullendirmede, ruhban sınıfı mensupları, krallığa tanrısal bir hüviyet kazandırılırken kralların tanrılar tarafından seçilmiş olduğunu güçlü biçimde vurgulamışlardır. Bunun ötesinde ruhban sınıfı mensupları, tanrılar tarafindan belirlenmiş olan krala verilen ilahi seçilmişliğin, soyundan gelen erkek evladına aktarıldığını iddia ederek siyasi istikrarı, tanrısal destekle sürdürmeye yardımcı olmuşlardır. Eskiçağdaki birçok toplumdaki bu genel kabullenişe rağmen taht mücadeleleri hiçbir zaman eksik olmamıştır.

Eskiçağdaki tüm krallıklarda benzer temel dinamiklere sahip taht mücadeleleri görülmesine rağmen çalışmamız, Hitit ve Mısır ile sınırlandırmış olduğundan bu döneme özgün örnekler üzerinden şekillendirilmiştir. Bu noktada her iki toplumda ortak olan yönler saptandığ 1 gibi bir diğerinden farklı özellikler de görülmüştür. Her iki krallıktaki ilk göze çarpan ortak özellik kralların hayatta iken kendilerinden sonra tahta geçecek bir veliaht belirlemesi olmuştur. Fakat I. Hattuşili'nin sağlığında veliaht belirlemiş olduğu yeğenin yanlış davranışları üzerinde onun yerine torunu Murşili'yi tahta çıkarması ve II. Seti'nin veliahdı olan Siptah'ın kral olmasına rağmen ülkeyi Kraliçe Tausret'in yönetmesi gibi örneklerde görüldügü üzere veliaht belirleme sistemi her zaman istenilen sonucu vermemiştir. $\mathrm{Bu}$ durumun temelinde kraliyet ailesi

\footnotetext{
${ }^{36}$ Breasted, age, s. 198 - 199.

${ }^{37}$ Hartwig Altenmüller, “Tausret und Sethnacht”, The Journal of Egyptian Archaeology, S. 68, 1982, s. 107 - 115.; Kathleen Kuiper, Ancient Egypt: From Prehistory to the Islamic Conquest, Rosen, New York 2011, s. 76.; J. Brett McClain - W. Raymond Johnson, "A Fragment from the Reign of Tausret Reused at Medinet Habu”, Journal of the American Research Center in Egypt, S. 49, 2013, s. 177 - 186.
} 
içerisindeki diğer taht namzetlerinin iktidara ulaşamama hırsından dolayı düzen bozucu faaliyetler içerisine girmesi bulunduğu gibi tahtı garantileyen veliahdın umursamaz tavırları da yer almaktadır.

Hitit ve Mısır Krallıklarında, taht mücadelelerinin ortaya çıkmasında kral adaylarının yokluğu kadar çokluğu da sorun teşkil etmiştir. Özellikle ileri yaşlara varmış olan kralların, yetişkinlik dönemini geçmiş olan oğulları arasında taht mücadelelerinin yaşanması kaçınılmaz hale gelmiştir. Fakat bu genellemenin bazı istisnaları da bulunmaktadır. Örneğin Hitit Kralı I. Şuppiluliuma'nın birçok erkek evladı bulunmasına rağmen en büyük oğlu olan II. Arnuvanda sorunsuz şekilde tahta geçmiştir. Fakat yaklaşık otuz erkek çocuğu olan II. Ramses'in ölümünden sonra oğulları arasında başlayan taht mücadelesi sülalenin yıkılışına kadar sürmüştür.

Mısır Krallığında, kral henüz hayatta iken belirlemiş olduğu veliahdın ortak krallık yapması sıklıkla kullanılan bir uygulama olup en bilinen örneği I. Ramses ile oğlu I. Seti’nin ilk dönemidir. Bu dönemde oldukça ileri bir yaşa sahip olan I. Ramses, saraydaki iç işleyişi sürdürürken oğlu I. Seti ise diğer tüm işleri yürütmekteydi. I. Ramses'in ölümü ile de I. Seti hiçbir itiraz ile karşılaşmadan tahta çıkmıştır. Mevcut kayıtlar, Hititlerde ortak krallık sisteminin kullanıldığına dair bir ipucu vermese de I. Şuppiluliuma'nın oğullarının yarı bağımsız kral olarak büyük kentlere yönetici olarak gönderdiği bilinmektedir.

Hitit Krallığındaki en kanlı taht mücadelelerinin kraliyet ailesine sonradan katılanlar tarafından çıkartıldığı bilinmektedir. Özellikle Hitit krallığının genişlemesi için büyük başarılar gösteren I. Murşili'den sonra ülkeyi yıkılmanın eşiğine getiren taht mücadelesi bunun en göze çarpan örneğidir. Mısır da ise kraliyete evlilik ile sonradan katılanların doğrudan taht için mücadelesinin ender örnekleri bulunsa dahi bu kişilerin kendi soyundan olan oğullarını kral yapma için saray entrikası düzenlemesine sıklıkla rastlanmaktadır. Hititler, yaşanan bu duruma, tahta çıkma sıralaması yaparak çözüm bulmaya gayret göstermiş olsalar da Misırlılar daha köktenci bir çözüm üreterek kraliyet ailesine katılımı sonlandırmış aile içi evlilik yapmanın önünü açmışlardır. Kraliyet ailesi içerisinde evlilik yapmanın bir tercihten çok zorunluluk olduğu ve kraliyetin bekası için bu yöntemin belirlendiği düşünülmektedir. Fakat bu evliliklerden çocuk olmayışı ve olanların da fiziksel özürlü oluşu bu sistemin uzun ömürlü olmayışını beraberinde getirmiştir. Hitit ve Mısır krallıkları, iç ve dış etkenlerin oluşturduğu sorunlar ile tarihleri boyunca mücadele ederken en sıkıntılı süreçler daima taht mücadeleleri döneminde yaşanmıştır.

Kaynakça

AKURGAL, Ekrem, Hatti ve Hitit Uygarlıklarl, Tükelmat, İzmir 1995.

ALDRED, Cyril, "The Parentage of King Siptah", The Journal of Egyptian Archaeology, S. 49, 1963 , s. $41-48$.

ALlEN, T. D., The Ancient Egyptian Family: Kinship and Social Structure, Routledge, Abingdon 2008.

ALP, Sedat, Hitit Çağında Anadolu, Tübitak, İstanbul 2000.

ALTENMÜLLER, Hartwig, "Tausret und Sethnacht”, The Journal of Egyptian Archaeology, S. 68, 1982, s. $107-115$.

ARCHI, Alfonso, "How the Anitta text reached Hattusa", Saeculum. Gedenkschrift für Heinrich Otten Anlässlich Seines, S. 100, 2015, s. $1-13$.

ASSMANN, Jan, The Mind of Egypt: History and Meaning in the Time of the Pharaohs, Harvard University Press, Harvard 2003. 
ATíLA, Nermin, "Hitit Devleti'nde Güvenlik Algısı", Tarih Araştırmaları Dergisi, C. 37, S. 64, 2018, s. $161-190$.

BAKER Rosalie F. - Charles F. Baker, Ancient Egyptians: People of the Pyramids, Oxford University Press, Oxford 2001.

BEAL, Richard H., "Studies in Hittite History", Journal of Cuneiform Studies, C. 35, S. 2, (1983), s. $115-126$.

BECKERATH, J. Von, "Queen Twosre as Guardian of Siptah", The Journal of Egyptian Archaeology, S. 48, 1962, s. $70-74$.

BECKMAN, Gary, "Inheritance and Royal Succession Among the Hittites", Assyriological Studies No: 23, The Oriental Institute of the University of Chicago Press, Chicago 1983, s. $13-31$.

BELL, Lanny, "Conflict and Reconciliation in the Ancient Middle East: The Clash of Egyptian and Hittite Chariots in Syria, and the World's First Peace Treaty between "Superpowers", War and Peace in the Ancient World, Ed. K. A. Raaflaub, Wiley-Blackwell, Malden 2007, s. $98-120$.

BREASTED, J. H., Ancient Records of Egypt: Historical Documents from the Earliest Times to the Persian Conquest (Vol. 3), University of Chicago Press, Chicago 1906.

BRYCE, Trevor Robert "Hattušili I and the Problems of the Royal Succession in the Hittite Kingdom”, Anatolian Studies, S. 31, 1981, s. 9 - 17.

BRYCE, Trevor Robert, "The Annals and Lost Golden Statue of the Hittite King Hattusili I", Gephyra, S. 16, 2018, s. $1-12$.

BRYCE, Trevor Robert, “The Death of Niphururiya and its Aftermath", The Journal of Egyptian Archaeology, C. 76, S.1, 1990, s. $97-105$.

BRYCE, Trevor Robert, The Kingdom of the Hittites, Oxford University Press, Oxford 2005.

BUDGE, E. A. W., Tutankhamen: Amenism, Atenism, and Egyptian Monotheism: with Hieroglyphic Texts of Hymns to Amen and Aten, Dover, Mineola 1991.

CALLENDER, Gae, "Female Horus: The Life and Reign of Tausret", Tausret: Forgotten Queen and Pharaoh of Egypt, Ed. Richard H. Wilkinson, Oxford University Press, Oxford 2012, s. $25-47$.

CALLENDER, Vivienne G., "Queen Tausret and the End of Dynasty 19", Studien zur Altägyptischen Kultur, S. 32, 2004, s. 81 - 104.

CANCIK - KIRSCHBAUM, Eva, Asurlular (Tarih, Toplum, Kültür), Çev: Aslı Yarbaş, İlya Yayınları, İzmir 2004.

CIFOLA, Barbara, "Ramses III and the Sea Peoples: A Structural Analysis of the Medinet Habu Inscriptions" Orientalia, C. 57, S. 3, 1988, s. $275-306$.

CLINE, E. H., MÖ. 1177 Medeniyetin Çöktüğü Yıl, Çev: Ayşegül Kuglin, Bilge Kültür Sanat, 2018.

COLLINS, B. J., "Hattušili I, the Lion King”, Journal of Cuneiform Studies, C. 50, S. 1, 1998, s. $15-20$. 
CREASMAN, Pearce Paul, "Hatshepsut and the Politics of Punt", The African Archaeological Review, C. 31, S. 3, 2014, s. $395-405$.

DELL, Pamela, Hatshepsut: Egypt's First Female Pharaoh, Compass Point Books, Minneapolis 2008.

DIJK, Jacobus van, "Horemheb and the Struggle for the Throne of Tutankhamun", Bulletin of the Australian Centre for Egyptology, S. 7,1996, s. 29 - 42.

DIJK, Jacobus van, "New Evidence on the Length of the Reign of Horemheb", Journal of the American Research Center in Egypt, S. 44, 2008, s. 193 - 200.

DİNÇOL, M. A. "Ashella Ritüeli (CTH 394) ve Hititlerde Salgın Hastalıklara Karşı Yapılan Majik İşlemlere Toplu Bir Bakış", Belleten, C. 49, S.193, Ankara 1985, s. 1 - 40.

DODSON, Aidan, "Messuy, Amada, and Amenmesse", Journal of the American Research Center in Egypt, S. 34, 1997, s. 41 - 48.

DODSON, Aidan, Amarna Sunset: Nefertiti, Tutankhamun, Ay, Horemheb, and the Egyptian Counter-Reformation, Oxford University Press, Oxford 2009.

DODSON, Aidan, Monarchs of the Nile, The American University in Cairo Press, Cairo 2000.

EPSTEIN, Claire, "That Wretched Enemy of Kadesh", Journal of Near Eastern Studies, C. 22, S. 4,1963 , s. $242-246$.

GARDINER, Alan, "Only One King Siptah and Twosre Not His Wife", The Journal of Egyptian Archaeology, S. 44, 1958, s. 12 - 22.

GARDINER, Alan, "The Tomb of Queen Twosre", The Journal of Egyptian Archaeology, S. 40, 1954 , s. $40-44$.

GAVAZ, Özlem Sir, "Hitit İmparatorluk Devri Krallarından I. Šuppiluliuma Döneminde Anadolu", Hitit Üniversitesi Sosyal Bilimler Enstitüsü Dergisi, C.1, S. 1, 2008, s. 21 - 39.

GAVAZ, Özlem Sir, "Hitit Kenti Zalpa'nın Yeri Üzerine”, Anadolu, S. 31. s. 1 - 18.

GILAN, Amir, "Hittite Ethnicity? Constructions of Identity in Hittite Literature", Anatolian Interfaces: Hittites, Greeks and Their Neighbours, Ed. Jean Collins, Mary R. Bachvarova, Ian Rutherford, Oxbow Books, Oxford 2008, s. 107 - 115.

GILES, F. J., "Amenhotpe, Ikhnaton and the Succession”, Aegyptus, C. 32, S. 2, 1952, s. 293 310.

GOEDEGEBUURE, Petra, “The Proclamation of Telipinu”, The Ancient Near East: Historical Sources in Translation, Ed. Mark W. Chavalas, Wiley-Blackwell, Malden 2006, s. 228 235.

GOEDICKE, Hans, "Considerations on the Battle of Kadesh", The Journal of Egyptian Archaeology, C. 52, S. 1, 1966, s. $71-80$.

GÜTERBOCK, H. G. “The Deeds of Suppiluliuma as Told by his Son, Mursili II (No:3)" Journal of Cuneiform Studies, C. 10, S. 3, 1956, s. 75 - 98.

HARDY, Robert S., "The Old Hittite Kingdom: A Political History", The American Journal of Semitic Languages and Literatures, C. 58, S. 2, 1941, s. 177 - 216.

HARRIS, J. R., "How Long Was the Reign of Horemheb?", The Journal of Egyptian Archaeology, S. 54, 1968, s. 95 - 99. 
HEAGY, T. C., "Who was Menes?”, Archéo-Nil, S. 24, 2014, s. 59 - 92.

HEALY, Mark, The Warrior Pharaoh: Ramses II and the Battle of Qadesh, Osprey, Oxford 1993, s. $19-82$.

HILLIARD, Kristina - Kate Wurtzel, "Power and Gender in Ancient Egypt: The Case of Hatshepsut", Art Education, C. 62, S. 3, 2009, s. 25 - 31.

HOFFMEIER, J. K., Akhenaten and the Origins of Monotheism, Oxford University Press, Oxford 2015.

HOPKINS, Keith, "Brother-sister Marriage in Roman Egypt", Comparative Studies in Society and History, C. 22, S. 3, 1980, s. $303-354$.

İNAN, Afet, Eski Mısır Tarih ve Medeniyeti, Türk Tarih Kurumu Yayınları, Ankara 1987.

KAWAI, Nozomu, "Ay Versus Horemheb: The Political Situation in the Late Eighteenth Dynasty Revisited", Journal of Egyptian History, C. 3, S. 2, 2010, s. 261 - 292.

KINAL, Füruzan, Eski Anadolu Tarihi, Türk Tarih Kurumu, Ankara 1998.

KITCHEN, K. A., Suppiluliuma and the Amarna Pharaohs: A Study in Relative Chronology, Liverpool University Press, Liverpool 1962.

KLENGEL, Horst, "Hitit Tarihi”, Hititler ve Hitit Imparatorluğu, Ed. Wenzel Jacob, Kunst-und Ausstellungshalle der Bundesrepublik Deu, Bonn 2002, 414 - 415.

KÖMÜRCÜ, Aysel, Hitit Krallığı'nda Veba Salgını ve Etkileri (M.Ö. II. Binyılın İlk Yarısı), Yayınlanmamış Yüksek Lisans Tezi, Afyon Kocatepe Üniversitesi, 2019.

KUHRT, Amelie, Eski Çağ'da Yakındoğu (M.Ö. 3000 - 330) Cilt: 1, Çev. Dilek Şendil, İş Bankası Kültür Yayınları, İstanbul 1995.

KUIPER, Kathleen, Ancient Egypt: From Prehistory to the Islamic Conquest, Rosen, New York 2011.

KUMAȘ, Arif, "Hitit Hukuki Metinlerinde Ataerkillik ve Anaerkillik Işı̆̆ında Veraset", Hitit Üniversitesi Sosyal Bilimler Enstitüsü Dergisi, ANARSAN Sempozyumu Özel Sayıs, Ekim 2018, C. 11, S. 2, s. 1497 - 1510.

LIVERANI, Mario, "The Great Powers' Club" Amarna Diplomacy: The Beginnings of International Relations, Ed. Raymond Cohen, Raymond Westbrook, The Johns Hopkins University Press, Baltimore 2002, s. 15 - 27.

LLOYD, Seton, Türkiye’nin Tarihi - Bir Gezginin Gözüyle Anadolu Uygarlıklarl, Tübitak, Ankara 1989.

MACQUEEN, J. G., Hititler ve Hitit Çağında Anadolu, Arkadaş Yayınları, Ankara 2013.

MARGETTS, Edward L., "The Masculine Character of Hatshepsut, Queen of Egypt", Bulletin of the History of Medicine, S. 25, 1951, s. $559-562$.

MARSMAN, H. J., Women in Ugarit and Israel: Their Social and Religious Position in the Context of the Ancient Near East, Brill Press, Leiden 2003, s. 384.

MCCLAIN, J. Brett - W. Raymond Johnson, "A Fragment from the Reign of Tausret Reused at Medinet Habu", Journal of the American Research Center in Egypt, S. 49, 2013, s. 177 186. 
MCLAUGHLIN, J. L., The Ancient Near East: An Essential Guide, Abingdon Press, Nashville 2012.

MIDDLETON, Russell, "Brother-sister and Father-daughter Marriage in Ancient Egypt" American Sociological Review, C. 27, S. 5, 1962, s. $603-611$.

MÕTTUS, Siim, The Edict of Telepinu and Hittite Royal Succession, Yayınlanmamış Doktora Tezi, 2018. University of Tartu.

NEWBERRY, Percy E., "King Ay, the Successor of Tut'ankhamon", The Journal of Egyptian Archaeology, C. 18, S. 1, 1932, s. $50-52$.

NORRIE, Philip, A History of Disease in Ancient Times: More Lethal than War, Springer, New York 2016.

O'CONNOR, David, "The Sea People and Egyptian Sources", The Sea Peoples and Their World: A Reassessment, Ed. E. D. Oren, University of Pennsylvania Press, Pennsylvania 2000, s. $85-102$.

PHILIPS, Allan K., "Horemheb, Founder of the XIXth Dynasty?", Orientalia, C. 46, S. 1, 1977, s. $116-121$.

REDFORD, D. B., "The Hyksos Invasion in History and Tradition", Orientalia, C. 39, S. 1, 1970, s. $1-51$.

SÄVE-SÖDERBERGH, Torgny, "The Hyksos Rule in Egypt", The Journal of Egyptian Archaeology, C. 37, S. 1, 1951, s. $53-71$.

SAYCE, A. H., "The Hyksos in Egypt”, The Biblical World, C. 21 S. 5, 1903, s. 347 - 355.

SETERS, John Van, In Search of History: Historiography in The Ancient World and the Origins of Biblical History, Eisenbrauns, Winona Lake, Indiana 1997.

SETERS, John Van, The Hyksos: A New Investigation, Wipf and Stock Publishers, Oregon 2010.

SINGER, Itamar, Hittite Prayers, Brill, Leiden 2002.

SPEISER, E. A., "Ethnic Movements in the Near East in the Second Millennium BC: The Hurrians and Their Connections with the Habiru and the Hyksos", The Annual of the American Schools of Oriental Research, S. 13, 1931, s. 13 - 54.

TEETER, Emily, "Museum Review: Hatshepsut and Her World", American Journal of Archaeology, C. 110, S. 4, 2006, s. $649-653$.

TORRI, Giulia, "Sargon, Anitta, and the Hittite Kings against Purušhanda", Altorientalische Forschungen, C. 36 S. 1, 2009, s. $110-118$.

TYLDESLEY, Joyce, "Foremost of Women: The Female Pharaohs of Ancient Egypt", Tausret: Forgotten Queen and Pharaoh of Egypt, Ed. Richard H. Wilkinson, Oxford University Press, Oxford 2012, s. 5 - 24.

ÜNAL, Ahmet - K. S. Girginer, Kilikya-Çukurova: İlk Çağlardan Osmanlılar Dönemi'ne Kadar Kilikya'da Tarihi Coğrafya, Tarih ve Arkeoloji, Homer Kitabevi, İstanbul 2007.

ÜNSAL, Veli, Eski Anadolu'da Teokratik Devlet Düzeni Hitit ve Urartu, Berikan Yayınevi, Ankara 2013.

WAINWEIGHT, G. A., "Some Sea-Peoples and Others in the Hittite Archives", The Journal of Egyptian Archaeology, C. 25, S. 1, 1939, s. $148-153$. 
WENGROW, David, The Archaeology of Early Egypt: Social Transformations in North-East Africa, c. 10.000 to 2.650 BC, Cambridge University Press, Cambridge 2006, s. $41-42$.

WILKINSON, T. A. H., "What a King is This: Narmer and the Concept of the Ruler", The Journal of Egyptian Archaeology, S. 86, 2000, s. 23 - 32.

YASUR-LANDAU, Assaf, The Philistines and Aegean Migration at the end of the Late Bronze Age, Cambridge University Press, Cambridge 2014.

YİĞìT, Turgut, "Eski Hitit Dönemine Ait Bir Ferman", Tarih Araştırmaları Dergisi, S. 41, 2007, s. $1-8$.

YİĞìT, Turgut, "Hitit Kral Ailesi Üyelerinin Siyasal Etkinlikleri Üzerine", Tarih Araştırmaları Dergisi, C. 18, S. 29, 1996, s. 233 - 245.

YİĞİT, Turgut, "Hitit Krallı̆̆ı'nda Veliahdın Belirlenmesi Üzerine”, Tarih Araştırmaları Dergisi, C. 22, S. 34, 2003, s. $141-147$.

YURCO, Frank J., "Was Amenmesse the Viceroy of Kush, Messuwy?", Journal of the American Research Center in Egypt, S. 34, 1997, s. 49 - 56. 